\title{
Evaluation of Hanford Tank Supernatant Availability for Technetium Management Project Studies in FY16
}

BM Rapko

\section{September 2015}




\title{
DISCLAIMER
}

This report was prepared as an account of work sponsored by an agency of the United States Government. Neither the United States Government nor any agency thereof, nor Battelle Memorial Institute, nor any of their employees, makes any warranty, express or implied, or assumes any legal liability or responsibility for the accuracy, completeness, or usefulness of any information, apparatus, product, or process disclosed, or represents that its use would not infringe privately owned rights. Reference herein to any specific commercial product, process, or service by trade name, trademark, manufacturer, or otherwise does not necessarily constitute or imply its endorsement, recommendation, or favoring by the United States Government or any agency thereof, or Battelle Memorial Institute. The views and opinions of authors expressed herein do not necessarily state or reflect those of the United States Government or any agency thereof.

\author{
PACIFIC NORTHWEST NATIONAL LABORATORY \\ operated by \\ BATTELLE \\ for the \\ UNITED STATES DEPARTMENT OF ENERGY \\ under Contract DE-AC05-76RL01830 \\ Printed in the United States of America \\ Available to DOE and DOE contractors from the \\ Office of Scientific and Technical Information, \\ P.O. Box 62, Oak Ridge, TN 37831-0062; \\ ph: (865) 576-8401 \\ fax: (865) 576-5728 \\ email: reports $\boldsymbol{a}$ adonis.osti.gov \\ Available to the public from the National Technical Information Service \\ 5301 Shawnee Rd., Alexandria, VA 22312 \\ ph: (800) 553-NTIS (6847) \\ email: ordersantis.gov <http://www.ntis.gov/about/form.aspx> \\ Online ordering: http://www.ntis.gov
}

This document was printed on recycled paper. 


\section{Evaluation of Hanford Tank Supernatant Availability for Technetium Management Project Studies in FY16}

BM Rapko

September 2015

Prepared for

the U.S. Department of Energy

under Contract DE-AC05-76RL01830

Pacific Northwest National Laboratory

Richland, Washington 99352 



\section{Executive Summary}

This report examines the need for actual Hanford tank waste solutions to support tasks in the Technetium Management Program in fiscal year (FY) 2016. One key need is to identify both samples where a majority of the soluble technetium is present as pertechnetate and samples where it is not. The total amount of tank supernatant needed from any given tank waste supernatant was determined by polling the tasks leaders for their technology testing needs in FY16 and then arbitrarily ascribing a 10\% process loss associated with consolidation and the Cs-137 removal needed to reduce the dose to a level suitable for testing in radiological fumehoods. These polling results identified a need for approximately 2.1 to $3.6 \mathrm{~kg}$ of any particular targeted Hanford tank waste supernatant.

It is assumed that the requested tank waste would come from archived samples currently stored at the Hanford Site's 222-S facility. Further, only tank samples removed from Hanford tanks in the last 5 years are deemed useful in order to minimize potential changes in Tc speciation as a result of extended storage. Such archived samples would be delivered to the Radiochemical Processing Laboratory (RPL) facility at Pacific Northwest National Laboratory (PNNL), where Cs-137 removal and subsequent subdividing of the tank samples would be performed before sending the aliquots to the Technetium Management Program task leads who requested samples.

Hanford tanks were identified that contain large fractions of both soluble Tc that are present either as pertechnetate or that are present as a non-pertechnetate species. Next, an inventory of samples currently stored at 222-S was obtained and the identified candidate tanks mapped against sample availability.

The results of this exercise indicate that only one tank waste supernatant dominant in soluble, nonpertechnetate technetium (AN-102, 2013 sampling event) and one tank waste supernatant dominant in soluble technetium as pertechnetate (AZ-102, either 2012 or 2014 sampling event) meet all above-mentioned criteria. Therefore, the recommendation is that at least $3.6 \mathrm{~kg}$ of AN-102 tank supernatant from the 2013 sampling event and all available AZ-102 tank supernatant from either the 2012 or 2014 sampling event be transferred from 222-S facility to the RPL at PNNL for FY16 testing.

Finally, efforts were made to ascertain whether suitable containers for such a transfer were currently available and whether the infrastructure (equipment, current procedures, etc.) was in place to package, ship, receive, and unpack the samples. Time limitations prevented some of these questions from being answered, but it should be noted that many similar transfers of Hanford tank supernatants from 222-S to RPL have been done in the past. 



\section{Acknowledgements}

This work was completed as part of the Technetium Management Hanford Site project. Support for this project came from the U.S. Department of Energy's Office of Environmental Management.

The author would like to thank MS Wilburn for editorial assistance and RJ Serne for his technical review. 



\section{Acronyms and Abbreviations}

FY

LAW

PNNL

QA

$\mathrm{R} \& \mathrm{D}$

RPL

SG

TCP

TIC

TOC

WRPS

WWFTP fiscal year (October 1 through September 30, e.g., FY 2015 ends on September 30, 2015)

low-activity waste

Pacific Northwest National Laboratory

quality assurance

research and development

Radiochemical Processing Laboratory

specific gravity

Tank Characterization Program

total inorganic carbon

total organic carbon

Washington River Protection Solutions

WRPS Waste Form Testing Program 



\section{Contents}

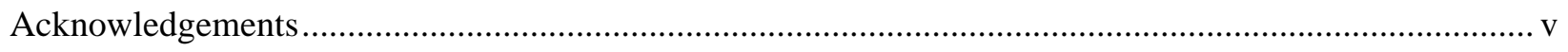

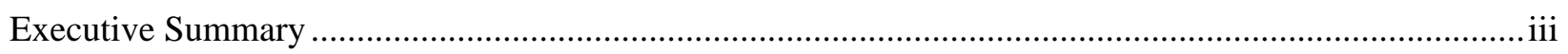

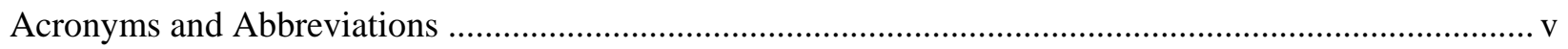

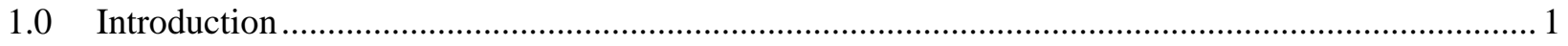

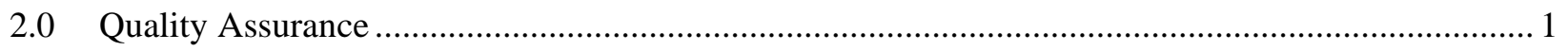

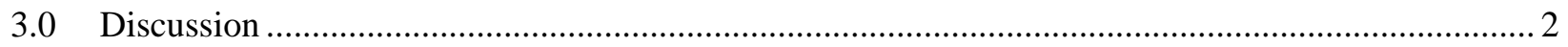

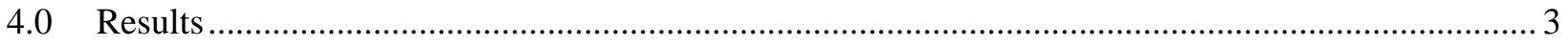

5.0 Selected Characterization Data for the Seven Candidate Tank Supernatants ................................ 6

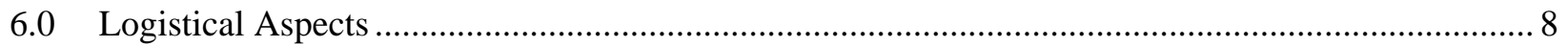

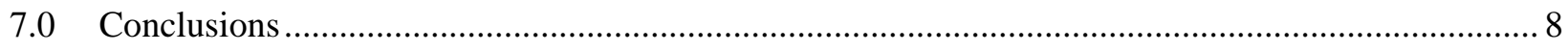

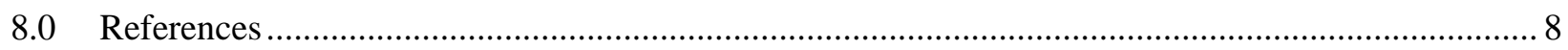

\section{Tables}

1. Sample Availability Table for Liquid Tank Wastes AN-102, AN-107, AP-104, AZ-101, AZ-102, SY-101, and SY-103 ............................................................................................... 4

2. Summary of Requested Tank Waste Information Network System Tank Data................................ 7 



\subsection{Introduction}

As described in the Technetium Management Project Test Plan (TP-EMSP-0018), ${ }^{1}$ Tc-99 (Tc) generated from the fission of ${ }^{235} \mathrm{U}$ and ${ }^{239} \mathrm{Pu}$ in high yields is a Hanford Nuclear Reservation tank waste constituent. Among radioactive constituents in the tank waste, Tc presents a unique challenge in that it has a long half-life $\left(\beta=292 \mathrm{keV} ; \mathrm{T}_{1 / 2}=2.11 \times 10^{5} \mathrm{y}\right)$ and exists predominantly in the liquid phase, generally in the anionic form of pertechnetate $\mathrm{TcO}_{4}{ }^{-}$, which is highly volatile at low-activity waste (LAW) vitrification melter temperatures and mobile in the Hanford Site's subsurface environment. This makes immobilization of Tc into high durability waste forms a critical technical challenge for nuclear waste management. The complex behavior of Tc under storage, treatment, and immobilization conditions significantly affects its management options, which to date remain uncertain.

To address the management challenges associated with the treatment, immobilization, and disposal of technetium in tank wastes, this project examines a number of technical challenges, including separation, disposition, and detection. A Test Plan describing a scope of study in fiscal year (FY) 2015 designed to address these technical challenges has been prepared (TP-EMSP-0018). The Test Plan breaks down the scope of study into seven tasks; Task 1 is to identify candidate Hanford tank waste supernatants for use in the other tasks as needed.

Specifically, as noted in Section 2.1 of the Technetium Management Project Test Plan, ${ }^{1}$ Task 1 seeks to identify candidate Hanford tank supernatants for technology testing under the Technetium Management Project beginning in FY16, determine their availability, and verify that the logistical aspects of shipping are in place for transfer from the Hanford Site's building 222-S to the Pacific Northwest National Laboratory (PNNL) Radiochemical Processing Laboratory (RPL). This report responds to this Task 1 scope.

\subsection{Quality Assurance}

This work was conducted as part of PNNL Project 54042 under the Technetium Management Program, with funding from the U.S. Department of Energy Office of Environmental Management.

All research and development (R\&D) work at PNNL is performed in accordance with PNNL's laboratory-level Quality Management Program, which is based on a graded application of NQA-1-2000, Quality Assurance Requirements for Nuclear Facility Applications, to R\&D activities. In addition to the PNNL-wide quality assurance (QA) controls, the QA controls of the Washington River Protection Solutions (WRPS) Waste Form Testing Program (WWFTP) QA program were also implemented for the work. The WWFTP QA program consists of the WWFTP Quality Assurance Plan (QA-WWFTP-001) and associated QA-NSLW-numbered procedures that provide detailed instructions for implementing NQA-1 requirements for R\&D work. The WWFTP QA program is based on the requirements of NQA-1-2008, Quality Assurance Requirements for Nuclear Facility Applications, and NQA-1a-2009, Addenda to ASME NQA-1-2008 Quality Assurance Requirements for Nuclear Facility Applications, graded on the approach presented in NQA-1-2008, Part IV, Subpart 4.2, “Guidance on Graded

\footnotetext{
${ }^{1}$ Levitskaia TG and DJ McCabe. 2015. Technetium Management - Hanford Site (FY 2015). TP-EMSP-0018, Rev 0.0, Pacific Northwest National Laboratory, Richland, WA.
} 
Application of Quality Assurance (QA) for Nuclear-Related Research and Development.” Preparation of this report was assigned the technology level "Applied Research" and was conducted in accordance with procedure QA-NSLW-1102, Scientific Investigation for Applied Research. All staff members contributing to the work have technical expertise in the subject matter and received QA training prior to performing quality-affecting work. The "Applied Research” technology level provides adequate controls to ensure that the activities were performed correctly. Use of both the PNNL-wide and WWFTP QA controls ensured that all client QA expectations were addressed in performing the work.

\subsection{Discussion}

Section 3.1 of TP-EMSP-0018 gives three criteria for supernatant selection: quantity, availability, and technetium speciation. These criteria can be summarized by the following questions:

1. Quantity: Is there sufficient material to support the three tasks charged with performing testing on/with actual Hanford tank waste supernatant in FY16? The three tasks requiring this material are Task 2, sensor development for n-Tc (alkaline soluble non-pertechnetate technetium or n-Tc); Task 3, Tc treatment and removal from LAW; and Task 6, non-glass waste forms for Tc immobilization.

2. Availability: Is the material available? Addressing this criterion involves confirming that the desired tank supernatant has not been reserved for other purposes.

3. Technetium speciation: Is there good reason to believe that at least one candidate tank supernatant has a substantial fraction of the soluble technetium not present as pertechnetate?

To this can be added a fourth criterion:

4. How will the identified samples be packaged at 222-S building, transported from 222-S to the RPL, and received at the RPL and stored before use? Addressing this criterion involves working with Hanford Site and PNNL shipping and the RPL's Shielded Facility Operations staff to verify that a mechanism exists to get the shipped containers into the RPL hot cells.

These criteria were addressed as follows. First, through WRPS, the current inventory of tank waste samples stored at the 222-S building as of summer 2015 was obtained. Next, it was assumed that only materials collected from those tanks that have been previously examined for their speciation of soluble technetium should be considered. Of these candidate materials, it was assumed that at least one tank supernatant should be from a tank in which the majority of its alkaline-soluble technetium is not in the form of pertechnetate and one supernatant should be from a tank where the majority of its soluble technetium is in the form of pertechnetate. Finally, the amount of tank supernatant needed was determined and mapped to the available tank supernatant inventory.

Next, the amount of material needed for FY16 testing was estimated by polling the leaders of Tasks 2, 3 , and 6 and totaling their individual requirements. Once the specific inventory items corresponding to the needed tank supernatants had been identified, it was noted whether there were flags indicating that the samples were reserved for other activities. Finally, attempts were made to ascertain the availability of shipping containers and the presence of qualified sample shippers and receivers. 


\subsection{Results}

A recent report by Serne et al. (2014, Table 4.9), and references therein, summarizes the published determinations of the fraction of alkaline soluble n-Tc in various tank supernatants. This table is the basis for selecting tanks most likely to have large fractions of n-Tc as well as tanks most likely to have minimal to no n-Tc present. It should be noted that this analysis assumes that the tank supernatant to be tested by each task should come from the same source (i.e., double-shell tank and sampling event). It also assumes that a relatively recently sampled supernatant should be used. For this tank supernatant candidate selection, "relatively recent" is defined as having been sampled no earlier than FY10 (roughly no longer than 5 years ago).

Inspection of Table 4.9 in Serne et al. 2014 reveals five tank supernatants, each with multiple measurements/estimates of the n-Tc/pertechnetate ratios, where half or more of the soluble Tc is present as n-Tc. These tanks are AN-102, AN-107, AP-104, SY-101, and SY-103. Two tanks were examined where little to no measurable n-Tc is present (AZ-101 and AZ-102), although there is one outlier measurement for AZ-102 that reports 33\% n-Tc against three measurements that indicate $<1 \% \mathrm{n}$-Tc. Thus, this first screening reduced the list of candidate tank supernatant to only seven tanks.

Next, the required amount of supernatant anticipated for the FY16 studies noted above was estimated and the availability of supernatant from these seven tanks noted. A polling of the relevant FY15 EMSP Tc Management task leaders led to the following estimates of needs for any Hanford tank supernatant: from Task 2 (SA Bryan), 50 to $100 \mathrm{~mL}$; from Task 3 (TG Levitskaia), 1.0 to $1.5 \mathrm{~L}$; and from Task 6 (W Um), 0.5 to $1 \mathrm{~L}$; for a total requested amount of 1.6 to $2.6 \mathrm{~L}$. As noted below, the typical density of the candidate Hanford tank supernatants is $1.25 \mathrm{~g} / \mathrm{mL}$, so the total mass needed (the inventory amounts are provided in kilograms) is 1.9 to $3.3 \mathrm{~kg}$. In addition, Cs-137 removal before testing is highly desirable; if a $10 \%$ loss during that processing step is assumed, ${ }^{2}$ a total target test sample of 2.1 to $3.6 \mathrm{~kg}$ per tank type is needed.

WRPS supplied a spreadsheet containing the current tank waste inventory from the Tank Characterization Program (TCP) stored at 222-S in early August of 2015. The inventory list provides information about source tank(s), sampling year, type of sampling, form (sludge, saltcake, liquid), and core ID (if applicable). Thus, the spreadsheet (inventory list) provides the information needed to determine which tank samples are available. It also notes whether the sample is currently reserved for other programmatic use.

The inventory list was first reduced to the seven candidate tanks noted above: AN-102, AN-107, AP-104, AZ-101, AZ-102, SY-101, and SY-103. Inspection of the inventory list reveals that the amount of supernatant needed highly restricts the sources of tank supernatant available and all but eliminates any archived sources of salt cake from selection. Availability of saltcake was included so that the use of dissolved saltcake as a backup to actual tank supernatant could be evaluated.

Table 1 summarizes the results from the TCP inventory archived at 222-S. We were particularly focused on the timing of the sampling event and restricted our focus to only events that occurred after 2010. For AN-102, there were two sampling events: one in 2012 and one in 2013. AN-107 had one

\footnotetext{
${ }^{2}$ Rapko et al. (2003) describe Cs-137 decontamination from dissolved Hanford Tank saltcake. Using data from the report and the original run notes, a $5 \%$ loss of feed from the operation is calculated.
} 
sampling event (in 2010), AP-104 had no sampling events over the period in question, AZ-101 had one sampling event (in 2010), and AZ-102 had two sampling events (one in 2012 and one in 2014). In addition, there was an AZ-101/AZ-102 composite sampling event in 2012, the nature of which was not investigated further.

As mentioned above, sample mass inventories significantly restrict the possibilities. With an identified need of 2.1 to $3.6 \mathrm{~kg}$ of sample, adequate amounts of tank supernatant are available only for the 2013 sampling (approximately $6 \mathrm{~kg}$ ) of AN-102 supernatant and either the 2012 sampling $(2.1 \mathrm{~kg})$ or the 2014 sampling (2.5 kg) of AZ-102 supernatant.

Table 1. Sample Availability Table for Liquid Tank Wastes AN-102, AN-107, AP-104, AZ-101, AZ102, SY-101, and SY-103

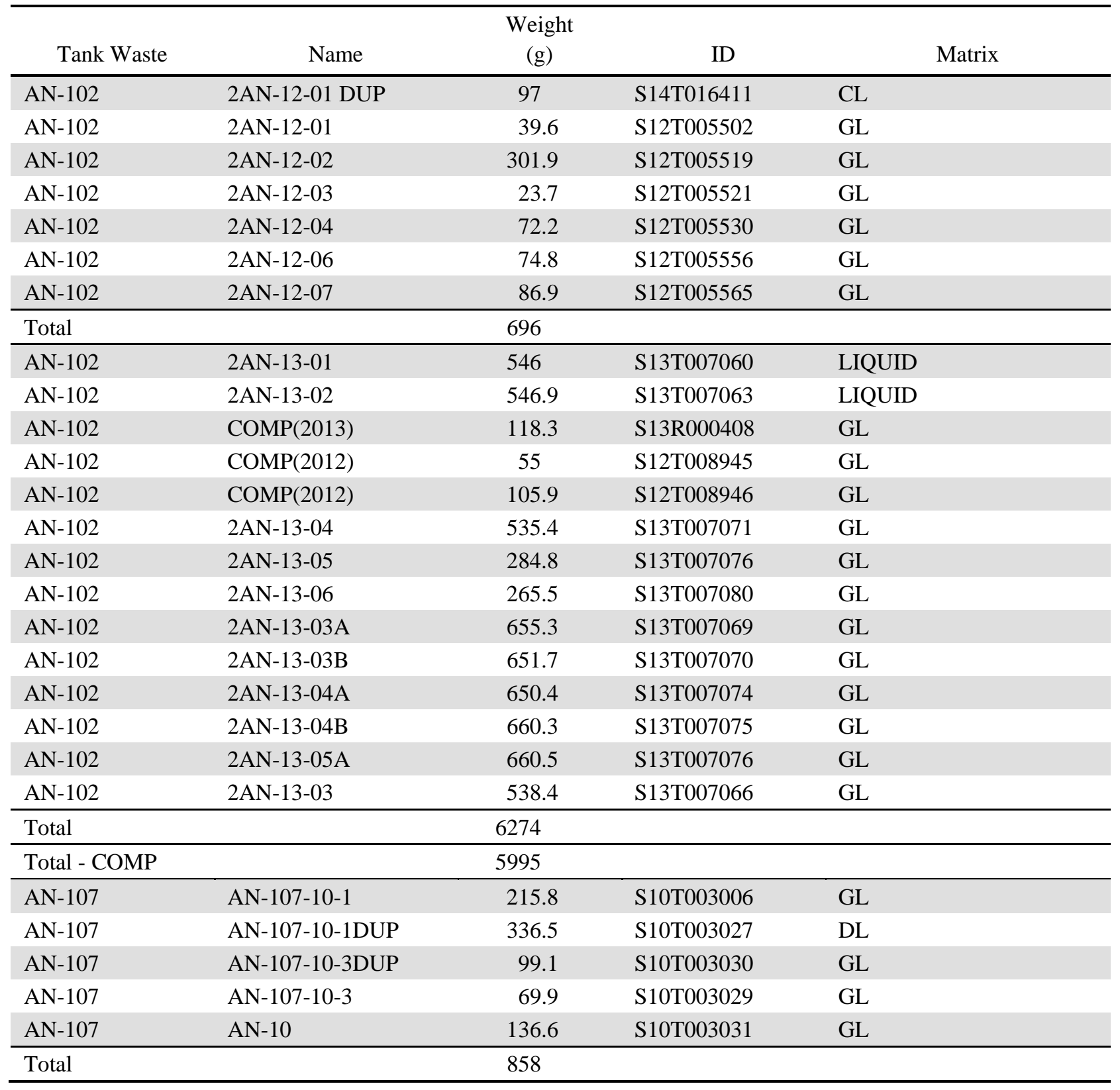




\begin{tabular}{|c|c|c|c|c|c|}
\hline \multicolumn{6}{|c|}{ Weight } \\
\hline Tank Waste & Name & (g) & ID & & Matrix \\
\hline AP-104 & NONE REPORTED & 190.1 & S07T001300 & GL & \\
\hline Total & & 190 & & & \\
\hline AZ-101 & AZ-101-10-6 & 7.2 & S10T000431 & GL & \\
\hline Total & & 7.2 & & & \\
\hline AZ101/AZ102 & NONE REPORTED & 529.5 & S12R000152 & LIQUID & \\
\hline AZ101/AZ102 & NONE REPORTED & 547 & S12R000152 & LIQUID & \\
\hline AZ101/AZ102 & NONE REPORTED & 549.5 & S12R000152 & LIQUID & \\
\hline Total & & 1626 & & & \\
\hline AZ-102 & 2AZ-12-01 & 112.1 & S12T014345 & GL & \\
\hline AZ-102 & 2AZ-12-01A & 245.2 & S12T014346 & GL & \\
\hline AZ-102 & 2AZ-12-01DUP & 144.5 & NONE & GL & \\
\hline AZ-102 & 2AZ-12-02 & 216.5 & S12T014368 & GL & \\
\hline AZ-102 & 2AZ-12-03 & 126.5 & S12T014370 & GL & \\
\hline AZ-102 & $2 \mathrm{AZ}-12-03 \mathrm{~A}$ & 228.9 & NONE & GL & \\
\hline AZ-102 & 2AZ-12-04 & 143.6 & S12T014418 & GL & \\
\hline AZ-102 & 2AZ-12-01DUP & 137 & S12T014429 & GL & \\
\hline AZ-102 & 2AZ-12-06 & 130.1 & S12T014451 & GL & \\
\hline AZ-102 & 2AZ-12-07 & 145.3 & S12T014440 & GL & \\
\hline AZ-102 & 2AZ-12-08 & 151.9 & S12T014473 & GL & \\
\hline AZ-102 & 2AZ-12-09 & 166.5 & S12T014484 & GL & \\
\hline AZ-102 & 2AZ-12-010 & 156 & S12T014495 & GL & \\
\hline Total & & 2104 & & & \\
\hline AZ-102 EVAP & 2AZ-14-01FB & 142.9 & S14T002802 & GL & \\
\hline AZ-102 EVAP & 2AZ-14-01 & 230.1 & S14T002898 & GL & \\
\hline AZ-102 EVAP & 2AZ-14-02 & 303.3 & S14T002902 & GL & \\
\hline AZ-102 EVAP & 2AZ-14-03DUP & 216.2 & S14T002919 & GL & \\
\hline AZ-102 EVAP & 2AZ-14-03A & 195.9 & S14T002930 & GL & \\
\hline AZ-102 EVAP & 2AZ-14-03B & 306.4 & S14T002936 & GL & \\
\hline AZ-102 EVAP & 2AZ-14-03C & 306.5 & S14T002935 & GL & \\
\hline AZ-102 EVAP & 2AZ-14-04A & 269.9 & S14T024358 & GL & \\
\hline AZ-102 EVAP & 2AZ-14-05A & 275.9 & S14T024371 & GL & \\
\hline AZ-102 EVAP & 2AZ-14-06 & 251.4 & S14T024373 & GL & \\
\hline Total & & 2499 & & & \\
\hline SY-101 & NONE & - & - & & - \\
\hline Total & & NA & & & \\
\hline SY-103 & - & 82 & S13T005351 & DL & \\
\hline SY-103 & - & 237.5 & S13T005350 & DL & \\
\hline Total & & 320 & & & \\
\hline $\begin{array}{l}\text { GL = grab sampl } \\
\text { Note that the nan } \\
\text { the name. }\end{array}$ & $\begin{array}{l}\text { uid; DL = drainable li } \\
\text { ad ID both record the } y\end{array}$ & $\begin{array}{l}\mathrm{L}=\text { centri } \\
\text { ormation }\end{array}$ & $\begin{array}{l}\text { liquid. } \\
S \text { in the ID an }\end{array}$ & $\operatorname{tank}$ fa & information in \\
\hline
\end{tabular}


Based only on having a measured n-Tc/pertechnetate ratio and sufficient sample availability, the list of preferred candidate tank supernatants can be reduced to two: the 2013 supernatant sampling of the high n-Tc-containing AN-102, and either the 2012 or 2014 samplings from the low n-Tc-containing AZ-102.

\subsection{Selected Characterization Data for the Seven Candidate Tank Supernatants}

Following requests by task leaders in the Technetium Management Project for selected characterization information about the candidate tank supernatants, a query was made to the Best Basis Inventory for characterization information from the initial seven candidate tank supernatants. The requested information included the supernatant's Sr, Tc-99, free hydroxide, Pd, Pt, Ru, and Rh concentrations; the supernatant's total organic carbon (TOC) and total inorganic carbon (TIC); and the supernatant's measured specific gravity (SG). The average values from multiple measurements are provided in Table 2.

There is little soluble strontium in these tank supernatants; the reported measurements are of total $\mathrm{Sr}$ rather than Sr-90 because of the lack of Sr-90 measurements for most of these samples. Few to none of the noble metals Pd, Pt, Ru, and Rh are detected. TOC and TIC concentrations vary widely, with TOC being more than an order of magnitude greater in AN-102 than AZ-102 and TIC in AN-102 also being greater, albeit to a lesser extent. Finally, AN-102 has a much greater specific gravity than in AZ-102. 
Table 2. Summary of Requested Tank Waste Information Network System Tank Data

\begin{tabular}{|c|c|c|c|c|c|c|c|c|c|c|c|c|}
\hline Tank & Year & $\begin{array}{c}{[\mathrm{Sr}]} \\
\mu \mathrm{g} / \mathrm{mL}\end{array}$ & SG & $\begin{array}{c}\text { TOC, } \\
\mu \mathrm{g} / \mathrm{mL}\end{array}$ & $\begin{array}{c}\text { TIC, } \\
\mu \mathrm{g} / \mathrm{mL}\end{array}$ & $\begin{array}{l}\text { Tc-99, } \\
\mu \mathrm{g} / \mathrm{mL}\end{array}$ & $\begin{array}{l}\text { Cs-137, } \\
\mu \mathrm{Ci} / \mathrm{mL}\end{array}$ & $\begin{array}{c}{[\mathrm{OH}]} \\
\mu \mathrm{g} / \mathrm{mL}\end{array}$ & $\begin{array}{c}\text { [Pd], } \\
\mu \mathrm{g} / \mathrm{mL}\end{array}$ & $\begin{array}{c}{[\mathrm{Pt}]} \\
\mu \mathrm{g} / \mathrm{mL}\end{array}$ & $\begin{array}{c}\text { [Rh], } \\
\mu \mathrm{g} / \mathrm{mL}\end{array}$ & $\begin{array}{r}{[\mathrm{Ru}],} \\
\mu \mathrm{g} / \mathrm{mL}\end{array}$ \\
\hline AN-102 & 2012 & $<6$ & 1.446 & 30,900 & 13,650 & 8.089 & 287 & 6659 & $<200$ & No Data & $<100$ & $<60$ \\
\hline AN-102 & 2013 & NA & NA & 22,233 & 12,400 & NA & NA & 9969 & NA & No Data & $<100$ & 22 \\
\hline AN-107 & 2010 & $<10$ & 1.421 & 36,533 & 15,683 & 5.576 & 278 & 12591 & $<100$ & No Data & $<50$ & $31 * * *$ \\
\hline AP-104 & $\begin{array}{c}\text { No } \\
\text { sample }\end{array}$ & - & - & - & - & - & - & - & - & - & - & - \\
\hline AZ-101 & 2010 & $<1.5$ & 1.232 & 533 & 8,513 & 20.083 & 1285 & 8483 & $66^{*}$ & No Data & $<25$ & $<15$ \\
\hline AZ-102 & 2012 & $<1$ & 1.136 & 476 & 4,262 & 4.284 & 247 & 6108 & 6 & No Data & $6^{*}$ & $4^{*}$ \\
\hline AZ-102 & 2014 & $<1$ & NA & 986 & 6,220 & NA & NA & 10577 & $<12$ & No Data & $<9$ & $4^{* *}$ \\
\hline SY-101 & $\begin{array}{c}\text { No } \\
\text { sample }\end{array}$ & - & - & - & - & - & - & - & - & - & - & - \\
\hline SY-103 & $\begin{array}{c}\text { No } \\
\text { sample }\end{array}$ & - & - & - & - & - & - & - & - & - & - & - \\
\hline $\begin{array}{l}* \text { Based } \\
* * \text { Only } \\
* * * \text { Only }\end{array}$ & $\begin{array}{l}\text { average } \\
\text { ta point } \\
\text { lata poil }\end{array}$ & $\begin{array}{l}\text { ll actua } \\
\text { thers < } \\
\text { others }\end{array}$ & red v & (less th & & gnored). & & & & & & \\
\hline
\end{tabular}




\subsection{Logistical Aspects}

An attempt was made to evaluate the readiness of the infrastructure for the packaging and shipment of targeted Hanford tank supernatants from 222-S and their receipt, unpackaging, and storage until needed at the RPL. Key questions included the availability and current readiness of suitable packaging for the shipment of these radioactive solutions, and the status of operating procedures to allow packaging of the tank supernatants at 222-S and their unpackaging and safe storage in the RPL hot cells.

No progress beyond the initial queries was made. However, such shipments have been fairly routine over the years and it is deemed likely that the documentation is current and in place for such sample transfers. The major unresolved question is the availability of suitable certified shipping containers.

\subsection{Conclusions}

This report was prepared to identify the best available tank waste supernatants for planned FY16 testing under the auspices of the Technetium Management Program. Both samples containing large fractions of supernatant-soluble Tc present as pertechnetate and samples containing soluble, nonpertechnetate Tc were desired. Determining the ratio of non-pertechnetate Tc to Tc present as pertechnetate requires specific, non-standard measurements. These measurements have only been performed with a few Hanford tank supernatants. Consideration of this subset of tank waste supernatants led to candidate supernatants from seven tanks: AN-102, AN-107, AP-104, AZ-101, AZ-102, SY-101, and SY-103. Considering the availability of recently collected samples from these tanks reduced the targeted candidates to two: the high n-Tc-containing supernatant from the 2013 sampling of AN-102 and the low n-Tc-containing supernatant from the 2012 sampling or the 2014 sampling of AZ-102.

Since tank waste samples, both sludges and solutions, are shipped from 222-S to the RPL, no difficulties in receiving these tank waste supernatants are expected, although an attempt to verify the presence and readiness of suitable shipping containers and the existence of a current, in-place infrastructure to perform such shipments was not verified but should be completed prior to any specific shipment scheduling.

\subsection{References}

NQA-1-2008, Quality Assurance Requirements for Nuclear Facility Applications. American Society of Mechanical Engineers, New York.

NQA-1a-2009, Addenda to ASME NQA-1-2008 Quality Assurance Requirements for Nuclear Facility Applications. American Society of Mechanical Engineers, New York.

Rapko BM, SI Sinkov, and TG Levitskaia. 2003. Removal of ${ }^{137}$ Cs from Dissolved Hanford Tank Saltcake by Treatment with IE-911. PNNL-14250, Rev. 1, Pacific Northwest National Laboratory, Richland, WA. 
Serne RJ, BM Rapko, and IL Pegg. 2014. Technetium Inventory, Distribution, and Speciation in Hanford Tanks. PNNL-23319, Rev. 1; EMSP-RPT-022, Rev. 1, Pacific Northwest National Laboratory, Richland, WA. 

PNNL-24768

EMSP-RPT-028, Rev. 0

\section{Distribution*}

U.S. Department of Energy

Office of Environmental Management

NP Machara

SP Schneider

Savannah River National Laboratory

D McCabe

\section{Pacific Northwest National Laboratory}

SA Bryan

TG Levitskaia

RA Peterson

BM Rapko

RJ Serne

Information Release

(PDF)

*All distribution will be made electronically. 




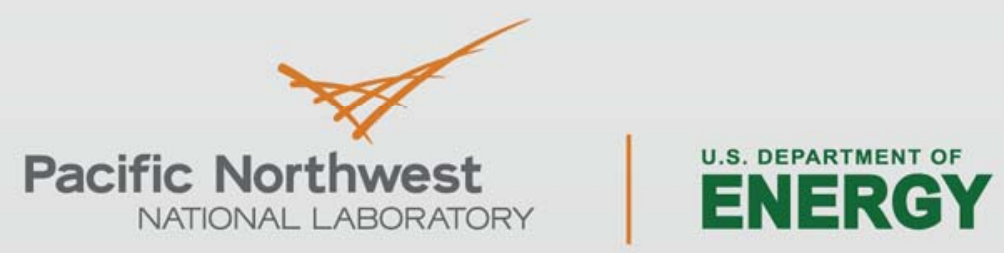

Proudly Operated by Battelle Since 1965

902 Battelle Boulevard

P.O. Box 999

Richland, WA 99352

1-888-375-PNNL (7665)

www.pnnl.gov 